\title{
URGENSI PERJANJIAN DALAM LALU LINTAS HUBUNGAN
}

\section{HUKUM PERDATA ${ }^{1}$}

\author{
Oleh : Rosdalina Bukido
}

\begin{abstract}
ABSTRAK
An agreement is an event of where a promising to another of where two the mans is each promise to execute a thing. Execution of this agreement become purpose of people whe make an agreement, because of exactly with execution of the agreement, the party making it will be able to fulfill it's the king be able to fulfill it's requirement.
\end{abstract}

Agreement is deed of real important law done by the parties in civil contractual terms before executing law deed. This thing is important is done for shake of creation of peacefulness and the parties justice. Agreement loads rights and obligations any kind of that must be done by the parties, so that if it is then day one them is default hance young referred to contents of agreement. Agreement gives protection of law the parties.

Kata kunci ; Agreement, law and justice.

\section{PENDAHULUAN}

A. latar belakang

1. Pengertian perjanjian

Suatu perjanjian merupakan suatu peristiwa dimana seorang berjanji kepada seorang lain dimana dua orang itu saling berjanji untuk melaksanakan suatu hal (Subekti,:1). Perjanjian menurut Pasal 1313 KUHPerdata adalah "suatu perbuatan dengan mana satu orang atau lebih mengikatkan dirinya terhadap satu orang atau lebih". Pengertian ini ternyata mendapat banyak kritikan karena di samping kurang lengkap juga dikatakan terlalu luas. Dikatakan kurang lengkap karena menyebutkan kata "perbuatan" tanpa menentukan jenis perbuatannya, seolah-olah juga mencakup tindakan seperti perwakilan sukarela, perbuatan melawan hukum dan lain sebagainya. Tindakan tersebut memang menimbulkan perikatan, akan tetapi perikatan tersebut timbulnya karena undang-undang, bukan karena perjanjian (Masjchoen Sofwan, 1980:1). Kemudian dari

\footnotetext{
${ }^{1}$ Dosen Hukum STAIN Manado
} 
kata "dengan mana satu orang atau lebih mengikatkan diri pada satu orang atau lebih'.didapat kesan seolah-olah perjanjian hanya mencakup perjanjian sepihak saja, sedangkan sebagian besar perjanjian merupakan peerjanjian timbal balik (Setiawan,1994:49).

Pengertian perjanjian 1313 KUHPerdata dikatakan terlalu luas karena mencakup pula perbuatan yang terletak dalam lapangan hukum keluarga, seperti pelangsungan perkawinan dan janji perkawinan. Perbuatan semacam ini memang menimbulkan perjanjian namun istimewa sifatnya, karena dikuasai oleh ketentuan tersendiri (Masjchoen Sofwan,1980:1) mengenai hubungan antara perjanjian dengan perikatan, Subekti, (2001:1) menyatakan bahwa suatu perjanjian adalah suatu peristiwa dimana seorang lain atau dimana dua orang itu saling berjanji untuk melaksanakan suatu hal. Dari peristiwa ini timbullah suatu hubungan hukum yang dinamakan perikatan. Perjanjian itu menerbitkan suatu perikatan antara dua orang yang membuatnya dengan demikian hubungan perjanjian dengan perikatan adalah bahwa perjanjian itu menimbulkan perikatan. Perjanjian merupakan sumber perikatan disamping sumber lainnya.

Pada awalnya perjanjian tidak hanya dipandang sebagai suatu perbuatan, tapi merupakan satu perbuatan hukum yang bersisi dua. Artinya bahwa dalam suatu perjanjian terdapat satu perbuatan hukum yang merupakan dua sisi. Sisi yang pertama adalah penawaran, sedangkan sisi ke dua adalah penerimaan. Pendapat ini juga mendapat banyak kritikan lalu lahirlah pendapat selanjutnya yang mengatakan bahwa perjanjian tidak lagi dianggap sebagai suatu perbuatan hukum yang bersisi dua, tetapi perjanjian merupakan dua perbuatan hukum yang masing-masing satu sisi sifatnya. Dua perbuatan hukum yang masing-masing satu sisi sifatnya. Dua perbuatan hukum tersebut adalah penawaran dan penerimaan. Penawaran dan penerimaan masing-masing menimbulkan akibat hukum. Oleh karena itu perjanjian merupakan dua perbuatan hukum yang masing-masing bersisi satu.

Pendapat umum para sarjana yang selama ini bertitik tolak pada Pasal 1313 KUHPerdata mengatakan bahwa perjanjian adalah suatu perbuatan hukum yang bersisi dua untuk menimbulkan persesuian kehendak guna melahirkan akibat hukum. Satu perbuatan hukum yang bersisi dua maksudnya adalah penawaran dan penerimaan. Penawaran dan penerimaan itu masing-masing pada hakikatnya adalah perbuatan hukum. Perbuatan hukum adalah perbuatan suyek hukum yang ditujukan untuk menimbulkan akibat hukum yang sengaja dikehendaki (Mertokusumo,1992:16). 
Berdasarkan hal tersebut di atas, maka perjanjian didefinisikan sebagai "hubungan hukum antara dua pihak atau lebih berdasarkan kata sepakat untuk menimbulkan akibat hukum “. Dua pihak itu sepakat untuk menentukan peraturan atau kaedah atau hak dan kewajiban, yang mengikat mereka untuk ditaati dan dijalankan. Kesepakatan itu adalah untuk menimbulkan akibat hukum, menimbulkan hak dan kewajiban dan kalau kesepakatan itu dilanggar maka ada akibat hukumnya, si pelanggar dapat dikenakan akibat hukum atau sanksi (Mertokusumo,1999:110).

\section{PEMBAHASAN}

1. Asas-asas hukum perjanjian

Asas hukum merupakan pikiran dasar yang umum dan abstrak, atau merupakan latar belakang peraturan konkrit yang terdapat dalam dan di belakang setiap sistim hukum yang terjelma dalam peraturan perundang-undangan dan putusan hakim yang merupakan hukum positif dan dapat ditemukan dengan mencari sifat-sifat atau ciri-ciri yang umum dalam peraturan konkrit (Mertokusumo,2001:5-6) dalam KUHPerdata terdapat beberapa asas hukum perjanjian yang berhubungan dengan lahirnya atau terjadinya perjanjian, isi perjanjian, akibat perjanjian, berlakunya perjanjian dan pelaksanaan perjanjian, yaitu:

a) Asas konsensualisme

Asas konsensualisme berhubungan dengan lahirnya perjanjian. Suatu perjanjian lahir atau terbentuk pada saat tercapainya kata sepakat (Konsensus) di antara para pihak mengenai unsuir pokok perjanjian. Adanya konsensus ini tidak memerlukan bentuk formalitas tertentu, sehingga bisa secara lisan maupun tertulis di bawah tangan maupun dengan akta otentik. Terhadap asas konsensualisme ini ada pengecualiannya yaitu oleh undang-undang diharuskan bentuk formalitas tertentu untuk beberapa perjanjian, dengan ancaman batalnya perjanjian tersebut apabila tidak dipenuhi. Contohnya adalah perjanjian penghibahan benda tak bergerak harus dilakukan dengan akta notaris, atau perjanjian perdamaian harus secara tertulis dan lain sebagainya. Perjanjianperjanjian tersebut dikenal sebagai perjanjian formil (Subekti,2001:16.) pengecualian lainnya pada perjanjian yang baru terjadi kalau barang yang menjadi pokok perjanjian telah diserahkan atau yang disebut sebagai perjanjian riil. Misalnya pada perjanjian penitipan barang, perjanjian utang piutang dan perjanjian pinjam-pakai yang baru terjadi dengan penyerahan barangnya. 


\section{b) Asas kebebasan berkontrak}

Asas kebebasan berkontrak berhubungan dengan isi perjanjian. Asas ini terdapat dalam Pasal 1338 ayat (1) KUHPerdata yang berbunyi: "semua perjanjian yang dibuat secara sah berlaku sebagai undang-undang bagi mereka yang membuatnya". Kata "semua" menyiratkan bahwa setiap orang bebas untuk mengadakan atau tidak mengadakan perjanjian, bebas memilih dengan siapa akan mengadakan perjanjian, bebas menentukan isi dan syarat-syarat perjanjian, bebas menentukan terhadap hukum mana perjanjian tersebut tunduk. Adanya kelima kebebasan tersebut menyebabkan Buku III KUHPerdata dikatakan menganut sistim terbuka. Sistim terbuka ini menjadikan Buku III KUHPerdata hanya bersifat sebagai hukum pelengkap, dimana ketentuan-ketentuan dalam Buku III KUHPerdata tersebut hanya berlaku jika para pihak tidak mengaturnya di dalam perjanjian yang mereka buat. Apabila para pihak telah mengaturnya secara menyimpang, maka ketentuan hukum pelengkap tersebut tidak digunakan.

c) Asas kekuatan mengikatnya perjanjian (pacta sunt servanda)

Asas ini berhubungan dengan akibat perjanjian. Apabila suatu perjanjian dibuat secara sah, maka perjanjian tersebut akan mengikat dan berlaku sebagai undang-undang bagi para pihak yang membuatnya. Maksudnya ialah para pihak wajib menaati isi perjanjian sebagaimana mereka menaati undang-undang. Pihak ketiga termasuk hakim, wajib menghormati isi perjanjian tersebut. Perkataan menghormati disini maksudnya ialah tidak mencampuri isi perjanjian yang telah dibuat oleh para pihak, dalam arti tidak menambah, mengurangi, ataupun menghilangkan kewajiban-kewajiban diantara para pihak. Oleh karena para pihak wajib menaati isi perjanjian, maka Pasal 1338 ayat (2) KUHPerdata menentukan bahwa suatu perjanjian yang telah ditutup tidak dapat ditarik kembali secara sepihak.

d) Asas kepribadian

Asas kepribadian berhubungan dengan berlakunya perjanjian. Pada umumnya tidak seorang pun dapat mengikatkan diri atas nama sendiri atau meminta ditetapkannya suatu janji, melainkan untuk dirinya sendiri. Inilah inti dari asas kepribadian seperti yang tercemin dalam Pasal 1315 dan dipertegas lagi dalam Pasal 1340 KUHPerdata yang menyatakan bahwa suatu perjanjian berlaku bagi pihak-pihak yang membuatnya.

e) Asas itikad baik

Asas itikad baik berhubungan dengan pelaksanaan perjanjian. Pasal 1338 ayat (3) KUHPerdata menyatakan bahwa "suatu perjanjian harus dilaksanakan dengan itikad baik". 
Berdasarkan asas itikad baik ini, maka hal-hal yang sudah diperjanjikan oleh para pihak dalam suatu perjanjian harus dilaksanakan sedemikian rupa sehingga dapat memenuhi rasa keadilan.

2.Syarat sahnya perjanjian

Pasal 1320 KUHPerdata menentukan bahwa untuk sahnya suatu perjanjian diperlukan 4 (empat) syarat yaitu:

a. Sepakat mereka yang mengikatkan dirinya

b. Kecakapan untuk membuat suatu perjanjian

c. Suatu hal tertentu

d. Suatu sebab yang halal.

Masing-masing syarat tersebut dapat dijelaskan sebagai berikut:

a. Sepakat mereka yang mengikatkan dirinya

Kata sepakat atau konsensus merupakan dasar lahirnya suatu perjanjian. Suatu perjanjian dianggap lahir atau terjadi pada saat tercapainya kata sepakat di antara para pihak yang mengadakan perjanjian. Kata sepakat merupakan suatu syarat yang logis karena dalam perjanjian setidak-tidaknya harus ada dua pihak yang saling berhadapan dan mempunyai dua kehendak yang saling mengisi. Pernyataan kehendak para pihak yang mengadakan perjanjian, dibedakan antara pernyataan kehendak yang merupakan penawaran dan pernyataan kehendak yang merupakan penerimaan. Suatu penawaran yang diikuti dengan penerimaan itulah yang menyebabkan lahirnya suatu perjanjian, karena persesuaian kehendak atau kata sepakat dianggap terjadi saat bertemunya kehendak untuk menawarkan dengan kehendak untuk menerima penawaran tersebut.

Kata sepakat atau konsensus mengandung pengertian bahwa para pihak saling menyatakan kehendak masing-masing untuk membuat suatu perjanjian, dimana kehendak pihak yang satu sesuai dengan pihak yang lain secara timbal balik. Pernyataan kehendak dapat dinyatakan secara tegas dengan kata-kata maupun dilakukan dengan perbuatan yang mencerminkan adanya kehendak untuk mengadakan perjanjian. Menurut J.Satrio, (2001:174-175) kehendak itu harus dinyatakan, harus nyata dan harus dapat dimengerti oleh pihak lain.

Pada hubungan yang bersifat langsung, dimana para pihak saling berhadapan langsung atau hubungan melalui telepon, saat terjadinya perjanjian sangat jelas, karena saat diterimanya penawaran dapat diketahui dengan segera oleh pihak yang menawarkan. Namun pada hubungan 
yang bersifat tidak langsung, misalnya surat-menyurat atau telegram, pihak yang menawarkan tidak dapat dengan segera mengetahui adanya penerimaan. Dalam keadaan seperti ini, sulit menentukan saat tercapainya persesuaian kehendak atau kata sepakat. Untuk mengatasi hal tersebut, kemudian dikemukakan empat teori, yaitu teori pernyataan, teori pengiriman, teori penerimaan, dan teori pengetahuan. Menurut teori pernyataan, kata sepakat terjadi pada saat dikeluarkannya pernyataan mengenai penerimaan suatu permintaan. Menurut teori pengiriman, kata sepakat lahir pada saat dikirimkannya jawaban atas penerimaan penawaran. Menurut teori penerimaan, kata sepakat terjadi pada saat diterimanya kehendak untuk menerima penawaran. Menurut teori pengetahuan, kata sepakat tercapai pada saat diketahui adanya kehendak untuk menerima penawaran, meskipun pengetahuan tersebut diperoleh oleh phak ketiga.

KUHP perdata tidaka menerangkan lebih lanjut apa yang dimaksud dengan kata sepakat dalam Pasal 1320 KUHPerdata. Pasal 1321 KUHPerdata menyebutkan bahwa "tiada sepakat yang sah apabila sepakat itu diberikan karena keikhlafan, atau diperolehnya dengan paksaan atau penipuan". Berdasarkan hal tersebut dapat disimpulkan bahwa yang dimaksud dengan kata sepakat dalam Pasal 1320 KUHPerdata adalah kata sepakat yang bebas, yaitu kata sepakat yang diperoleh bukan karena keikhlafan, paksaan dan penipuan. Keikhlafan dan kesesatan, paksaan dan penipuan merupakan faktor-faktor yang menyebabkan terjadinya cacat kehendak.

Ada dua macam kesesatan, pertama, kesesatan dalam arti yang sesungguhnya, dalam arti sesungguhnya, dalam kesesatan ini terjadi konsensus atau kata sepakat. Ada kehendak dan pernyataan kehendak yang sama namun salah satu pihak memiliki gambaran yang keliru. Kedua, kesesatan dalam arti tidak sesungguhnya, disini tidak terjadi konsesus atau kata sepakat, maka dengan sendirinya tidak ada perjanjian. Paksaan adalah perbuatan sedemikian rupa pamenimbullkan ketakutan pada seseorang bahwa diri maupun kekayaannya terancam oleh suatu kerugian yang terang dan nyata. Pasal 1323 KUHPerdata menyatakan bahwa paksaan yang dilakukan terhadap orang yang membuat suatu persetujuan merupakan alasan untuk batalnya persetujuan.

Pasal 1328 KUHPerdata menyebutkan bahwa penipuan merupakan alasan untuk pembatalan persetujuan, apabila tipu muslihat yang dipakai oleh salah satu pihak adalah sedemikian rupa hingga terang dan nyata bahwa pihak yang lain tidak akan membuat perikatan itu jika tidak dilakukan tipu muslihat tersebut. Adanya penipuan tidak boeh hanya dipersangkaan tapi benarbenar harus dibuktikan dalam perkembangannya terdapat faktor penyebab cacat kehendak yang 
lain, yaitu penyalahgunaan keadaan. Penyalahgunaan keadaan terjadi apabila salah satu pihak dalam perjanjian, berdasarkan keunggulannya di bidang ekonomi atau status sosial, melakukan tekanan kepada pihak lain sedemikian rupa sehingga pihak yang tertekan terpaksa menyetujui untuk menutup suatu perjanjian dengan ketentuan yang sangat memberatkan pihaknya.

b. Kecakapan untuk membuat suatu perjanjian

Pasal 1329 KUHPerdata menyebutkan bahwa "setiap orang adalah cakap untuk membuat perikatan-perikatan, jika ia oleh undang-undang tidak dinyatakan tidak cakap". Berdasarkan ketentuan tersebut diketahui bahwa pada umunya setiap orang dianggap cakap untuk membuat perjanjian, kecuali mereka yang secara tegas dianggap tidak cakap oleh undangundang. Pasal 330 ayat(1) KUHPerdata menyebutkan bahwa belum dewasa adalah mereka yang belum mencapai umur genap 21 tahun dan tidak lebih dulu kawin. Secara a contrario dapat ditarik kesimpulan bahwa seseorang dianggap dewasa apabila telah berusia 21 tahun atau telah menikah. Jika seseorang diletakkan di bawah pengampuan, maka secara yuridis orang tersebut juga dianggap tidak cakap untuk melakukan perbuatan hukum. Berdasarkan hal tersebut di atas, maka dapat disimpulkan bahwa yang cakap untuk melakukan perbuatan hukum menurut KUHPerdata adalah telah genap berusia 21 tahun atau telah menikah dan sepanjang yang bersangkutan tidak ditempatkan di bawah pengampuan.

c. Suatu hal tertentu

Suatu hal tertentu sebagai syarat ketiga mempunyai 2 (dua) pengertian. Pertama, bahwa yang dimaksud dengan suatu hal tertentu adalah barang atau benda yang sudah ditentukan, sebagaimana disebutkan dalam Pasal 1333 dan Pasal 1334 KUHPerdata. Kedua, bahwa yang dimaksud dengan suatu hal tertentu adalah prestasi dalam perjanjian (EL Rahman,2000:18). Dari kedua pengertian tersebut dapat disimpulkan bahwa suatu hal tertentu juga merupakan pokok perjanjian atau obyek perjanjian.

d. Suatu sebab yang halal

Sebab yang dimaksud dalam suatu perjanjian adalah isi dari perjanjian itu sendiri (Subekti,2001:20). KUHPerdata tidak secara tegas memberikan pergertian mengenai sebab yang halal. Pasal 1337 KUHPerdata menyebutkan bahwa suatu sebab adalah terlarang, apabila dilarang oleh undang-undang, atau apabila berlawanan dengan kesusilaan atau ketertiban umum. Dari Pasal ini dapat ditarik kesimpulan bahwa yang dimaksud dengan halal adalah bahwa perjanjian tidak boleh bertentangan dengan undang-undang, kesusilaan dan ketertiban umum. 
Dengan demikian maka yang dimaksud dengan sebab yang halal adalah isi perjanjian yang tidak boleh bertentangan dengan undang-undang, kesusilaan dan ketertiban umum.

\section{Unsur-unsur perjanjian}

Unsur perjanjian ada 3 (tiga) yakni:

a. Unsur essensialia

Unsur essensialia adalah unsur perjanjian yang harus selalu ada dalam suatu perjanjian atau disebut juga unsur mutlak. Unsur ini mutlak harus ada agar perjanjian itu sah atau merupakan syarat sahnya perjanjian. Syarat sahnya perjanjian sebagaimana terdapat dalam Pasal 1320 KUHPerdata yakni adanya kata sepakat, kecakapan untuk membuat perjanjian, suatu hal tertentu dan suatu sebab yang halal.

\section{b. Unsur naturalia}

Unsur naturalia adalah unsur yang melekat pada perjanjian atau merupakan bagian dari suatu perjanjian yang tanpa disebutkan dengan tegas dianggap ada dalam perjanjian tersebut. Contohnya dalam perjanjian jual-beli, tanpa disebutkan dengan tegas, penjual harus menjamin pembeli terhadap cacat tersembunyi.

c. Unsur accidentalia

Menurut Mertokusumo, (1999:111) unsur accidentalia adalah unsur yang harus dimuat secara tegas dalam perjanjian. Unsur ini harus secara tegas diperjanjikan, misalnya mengenai tempat tinggal yang dipilih.

\section{Jenis- jenis perjanjian}

Pembedaaan perjanjian berdasarkan akibat hukum yang muncul yaitu ditinjau dari sistematika hukum atau termasuk dalam bidang hukum yang mana, maka dibedakan dalam berbagai macam yaitu:

a. Perjanjian kekeluargaan

Hukum keluarga merupakan bagian dari hukm perorangan. Salah satu bagian penting dari hukum keluarga adalah hukum perkawinan. Hukum perkawinan merupakan keseluruhan peraturan yang mengatur tentang perkawinan. Pada asasnya perkawinan didasarkan atas kata sepakat dan menimbulkan hak dan kewajiban antara kedua calon suami isteri, tetapi akibat hukum yang ditimbulkan hanya dalam hukum keluarga saja dan hak serta kewajiban tersebut ada di luar hukum kekayaan, kecuali yang ada dalam lapangan hukum harta perkawinan. Jadi 
perkawinan sebenarnya juga merupakan suatu perjanjian, tetapi perjanjian ini berbeda dengan perjanjian menurut Buku III KUHPerdata (Afandi,1986:86).

b. Perjanjian kebendaan

Perjanjian kebendaan dimaksudkan untuk mengoperkan, mengalihkan benda atau hak atas benda, di samping untuk menimbulkan, mengubah atau menghapuskan hak kebendaan. Perjanjian kebendaan pada umumnya merupakan pelaksanaan dari suatu perjanjian obligator. Perjanjian obligator menimbulkan kewajiban-kewajiban antara lain untuk menyerahkan objek perjanjian dan sekaligus perjanjian obligatoir diadakan dengan tujuan untuk mengoper hak kebendaan. Oleh karena itu maka perjanjian obligatoir diikuti dengan perjanjian kebendaan (Satrio,1992:48-49). Perjanjian kebendaan diatur dalam Buku III KUHPerdata.

c. Perjanjian obligatoir

Perjanjian obligatoir adalah perjanjian yang menimbulkan perikatan, artinya sejak terjadinya perjanjian, timbullah hak dan kewajiban para pihak (Muhammad,1992:87). Pada asasnya perjanjian obligatoir baru melahirkan perikatan saja, dalam arti bahwa hak atas objek perjanjian belum beralih. Untuk peralihannya masih diperlukan adanya pernyerahan (Satrio,1993:38). Perjanjian obligatoir dapat dibedakan dalam berbagai macam, yaitu:

1. Berdasarkan hak dan kewajiban para pihak.

Berdasarkan hak dan kewajiban para pihak dikenal dua macam perjanjian yaitu:

a) Perjanjian timbal balik

Perjanjian timbal balik merupakan perjanjian yang menimbulkan kewajibankewajiban dan karenanya hak juga kepada kedua belah pihak di mana hak dan kewajiban itu mempunyai hubungan satu dengan yang lainnya, misalnya pada perjanjian sewa-menyewa dan perjanjian tukar-menukar (Satrio,2001:43-44)

b) Perjanjian sepihak

Perjanjian sepihak merupakan perjanjian yang menimbulkan kewajiban pada satu pihak saja, misalnya pada perjanjian pinjam-meminjam (Vollmar,1984:130). Di antara keduanya ada perjanjian timbal balik tidak sempurna. Perjanjian yang demikian pada dasarnya adalah perjanjian sepihak karena kewajiban pokoknya hanya ada pada salah satu pihak saja, tetapi dalam hal-hal tertentu timbul kewajiban kewajiban pada pihak lain. Contohnya adalah pemberian kuasa (Satrio,1992:38). 
2. Berdasarkan keuntungan salah satu pihak dan adanya prestasi dari pihak lainnya

Berdasarkan keuntungan salah satu pihak dan adanya prestasi dari pihak lainnya maka perjanjian ada dua macam, yaitu perjanjian atas beban dan perjanjian Cuma-Cuma. Perjanjian atas beban adalah perjanjian di mana terhadap prestasi pihak yang satu terdapat prestasi pihak yang lain dan antara kedua prestasi tersebut terdapat hubungan hukum satu dengan yang lain. Adapun perjanjian Cuma-Cuma adalah perjanjian di mana salah satu pihak mendapatkan keuntungan dari pihak yang lain secara Cuma-Cuma, misalnya perjanjian pinjam- pakai (Setiawan,1994:50).

3. Berdasarkan nama dan pengaturannya

Berdasarkan cara terjadinya atau cara lahirnya perjanjian.

4. Berdasarkan nama dan pengaturannya.

Pasal 1319 KUHPerdata menyebutkan 2 (dua) kelompok perjanjian, yakni perjanjian bernama dan perjanjian tak bernama. Perjanjian bernama adalah perjanjian dengan nama tertentu yang telah diatur secara khusus dalam perundang-undangan, baik KUHPerdata, KUHD, maupun dalam peraturan yang dibentuk secara khusus untuk mengatur perjanjian tersebut. Oleh karena diatur secara khusus tersebut, maka perjanjian bernama juga dikenal dengan perjanjian khusus. Perjanjian tak bernama adalah perjanjian yang timbul dalam masyarakat yang belum diatur secara khusus dalam undang-undang serta belum diberi nama resmi atau disebut juga perjanjian jenis baru, karena perjanjian tersebut baru lahir setelah terbentuknya kodifikasi KUHPerdata maupun KUHD. Perjanjian jenis baru terdiri dari perjanjian jenis baru yang bersifat khusus (contractus sui generis) dan perjanjian campuran. Perjanjian campuran adalah perjanjian yang mempunyai cirri-ciri dari dua atau lebih perjanjian bernama. Contohnya perjanjian in the kost antara anak kost dengan induk semangnya. Di dalam perjanjian yang demikian terdapat unsur-unsur yang mirip atau sama dengan perjanjian sewa-menyewa yaitu menyediakan kamar untuk tinggal, perjanjian untuk melakukan pekerjaan tertentu yaitu pemeliharaan dan pelayanan serta perjanjian pemborongan yaitu pemeliharaan dan pelayanan serta perjanjian pemborongan yaitu menyediakan makan (Satrio,2001:151). Apabila dalam perjanjian campuran timbul sengketa, maka pedoman penyelesaiannya adalah dengan menggunakan 3 (tiga) teori, yakni: 
a) Teori kombinasi

Berdasarkan teori ini, jika timbul sengketa dalam suatu perjanjian campuran, maka yang berlaku adalah semua ketentuan dalam perjanjian-perjanjian yang unsur-unsurnya terdapat dalam perjanjian campuran tersebut.

b) Teori absorpsi

Berdasarkan teori ini, jika ketentuan dalam perjanjian yang insur-unsurnya terdapat dalam perjanjian campuran tersebut bertentangan satu sama lain, maka yang digunakan adalah ketentuan-ketentuan dari perjanjian yang unsurnya paling dominan

c) Teori contractus sui generis

Menurut teori ini, perjanjian campuran dianggap sebagai perjanjian jenis baru yang mempunyai sifat khusus, sehingga jika terjadi sengketa maka penyelesaiannya sama seperti penyelesaian perjanjian jenis baru yang mempunyai sifat khusus (sui generis).

d. Perjanjian pembuktian

Perjanjian pembuktian adalah suatu perjanjian yang mengatur tentang pembuktian yang akan berlaku antara para pihak yang mengadakan perjanjian tersebut (Subekti,2001:65).

\section{Perjanjian baku}

Dilihat dari segi bentuk, perjanjian dapat dibuat dalam bentuk lisan atau tulisan. perkembangannya, kebanyakan perjanjian dibuat dalam bentuk tertulis. Bentuk tertulis yang berkembang saat ini cenderung berbentuk baku atau standar. Perjanjian-perjanjian yang dibuat .dalam bentuk baku sesuai dengan kecenderungan masyarakat yang menginginkan segala sesuatu yang bersifat praktis. Menurut Sjahdeini, (1993:66) perjanjian baku adalah perjanjian yang hampir seluruh klasula-klasulaunya sudah dibakukan oleh pemakaiannya dan pihak yang lain pada dasarnya tidak mempunyai peluang untuk merundingkan atau meminta perubahan. Mertokusumo, (1990:4) mempergunakan istilah "kontrak standar" untuk menyebut perjanjian baku, yang didefinisikan sebagai suatu kontrak yang isinya ditentukan secara a priori oleh salah satu pihak yang mempunyai kedudukan lebih unggul.

Bolger sebagaimana dikutip oleh Badrulzaman, (1994:46) menyebut perjanjian standar sebagai take it or leave it contract, karena perjanjian standar bersifat massal dan kolektif, artinya jika debitur mungkin hanya bersikap menerima atau tidak menerimanya sama sekali dan 
kemungkinan untuk mengadakan perubahan-perubahan sama skalitidak ada. Badrulzaman, (1994:49-50) membagi perjanjian baku menjadi 3 jenis yaitu:

a) Perjanjian baku sepihak, adalah perjanjian yang isinya ditentukan oleh pihak yang kuat kedudukannya di dalam perjanjian itu. Pihak yang kuat biasanya adalah pihak kreditur yang biasanya mempunyai posisi kuat dibandingkan pihak debitur, dalam jenis perjanjian ini, kedua belah pihak lazimnya terikat dalam organisasi formal, misalnya pada perjanjian buruh kolektif.

b) Perjanjian baku yang ditetapkan oleh pemerintah, yaitu perjanjian baku yang isinya ditentukan oleh pemerintah terhadap perbuatan-perbuatan hukum tertentu, misalnya berkaitan dengan perjanjian yang mempunyai objek hak-hak atas tanah

c) Perjanjian baku yang ditentukan dalam lingkungan notaris atau advokat. Di lingkungan notaris atau advokat terdapat perjanjian-perjanjian yang sejak semula konsepnya sedah disediakan untuk memenuhi permintaan dari anggota masyarakat. Di dalam perjanjian baku sering dipersoalkan mengenai ada tidaknya unsur kesepakatan dalam perjanjian tersebut, mengingat adanya perbedaan kedudukan para pihak, di mana pihak yang lemah terpaksa harus menerima isi perjanjian. Badrulzaman,(1994:52) mengatakan bahwa secara teoritis yuridis perjanjian baku tidak memenuhi elemen-elemen yang dikehendaki oleh Pasal 1320 Jo. Pasal 1338 ayat (1) KUHPerdata. Hal ini dikarenakan adanya perbedaan posisi para pihak pada saat perjanjian baku diadakan, pihak debitur tidak memperoleh kesempatan untuk mengadakan bargaining dengan kreditur. Debitur tidak mempunyai kekuatan untuk mengutarakan kehendak dan kebebasannya dalam menentukan isi perjanjian tersebut. Pendapat yang lain mengatakan bahwa untuk menentukan ada atau tidaknya kata sepakat dalam perjanjian baku, harus dilihat terlebih dahulu bagian-bagian dari perjanjian baku. Perjanjian baku terdiri dari 3 bagian, yaitu:

1) Bagian perjanjian pokok

2) Bagian perjanjian tambahan atau pelengkap

3) Bagian syarat-syarat baku atau standar.

Mengenai bagian perjanjian pokok dan bagian perjanjian tambahan atau pelengkap terdapat kata sepakat, sedangkan dalam bagian syarat-syarat baku atau standar tidak terdapat kata sepakat para pihak. Namun demikian, ketiga bagian tersebut merupakan satu kesatuan yang tidak dapat dipisahkan. Dengan demikian dapat dikatakan bahwa dalam standar kontrak dianggap terdapat 
kata sepakat dari pihak yang membuat perjanjian. Sedangkan penulis-penulis Perancis berpendapat bahwa perjanjian baku bukanlah merupakan perjanjian, tetapi merupakan hubungan hukum yang sui generis atau hubungan hukum yang lain dari pada yang lain (Mertokusumo,1990:4).

6. Wanprestasi dan akibatnya

Sebagaimana dijelaskan sebelumnya, bahwa kata sepakat merupakan salah satu syarat sahnya perjanjian. Adanya kata sepakat tesebut menimbulkan hak dan kewajiban atas suatu prestasi antara para pihak. Akan tetapi adakalanya debitur tidak melaksanakan pemenuhan prestasi sebagaimana mestinya, sehingga debitur dikatakan telah melakukan wanprestasi. Wanprestasi berarti tidak dilaksanakannya prestasi yang telah diperjanjikan karena kesalahan debitur, baik disengaja maupun karena kelalaian tidak dalam kondisi memaksa dan telah ditegur. Menurut Subekti, (2001:45) wanprestasi seorang debitur dapat berupa:

a. Tidak melakukan apa yang telah disanggupinya untuk dilakukan;

b. Melaksanakan apa yang telah diperjanjikan, akan tetapi tidak sebagaimana mestinya;

c. Melakukan apa yang telah diperjanjikan, tetapi terlambat;

d. Melakukan sesuatu yang menurut perjanjian tidak boleh dilakukan.

Mengenai bagaimana caranya memperingatkan seorang debitur maka Pasal 1238 KHUPerdata menyebutkan bahwa Si berutang adalah lalai, apabila ia dengan surat perintah atau dengan sebuah akta sejenis itu telah dinyatakan lalai, atau demi perikatannya sendiri, ialah jika ini menetapkan bahwa si berutang harus dianggap lalai dengan lewatnya waktu yang ditentukan.

Dari ketentuan tersebut diketahui bahwa seorang debitur baru dapat dikatakan wanprestasi apabila ia tetap tidak melaksanakan prestasinya sedangkan kepadanya telah diberikan teguran atau somasi. Walaupun begitu, dalam beberapa hal somasi tidak diperlukan apabila:

a) Perjanjian tersebut memuat ketentuan batas waktu;

b) Prestasi yang diharapkan dalam perjanjian tersebut adalah tidak berbuat sesuatu;

c) Debitur mengakui bahwa dirinya wanprestasi.

Menurut Pasal 1267 KUHPerdata apabila debitur melakukan wanprestasi, maka keditur dapat menuntut yang berupa pilihan yaitu; pemenuhan perjanjian, pemenuhan perjanjian serta ganti rugi, ganti rugi saja, pembatalan perjanjian dan pembatalan perjanjian disertai ganti rugi. 
Pasal 1243 KUHPerdata menentukan bahwa penggantian kerugian karena wanprestasi meliputi 3 hal yaitu:

a) Biaya, yaitu segala pengeluaran atau perongkosan yang nyata-nyata telah dikeluarkan oleh kreditur

b) Rugi, yaitu keugian karena kerusakan barang-barang kepunyaan kreditur yang diakibatkan oleh kelalaian debitur.

c) Bunga, yaitu kerugian yang berupa kehilangan keuntungan yang diharapkan didapatkan oleh kreditur atau jika dalam keadaan debitur tidak wanprestasi (Subekti,2001:47).

7. Keadaan memaksa

Dari ketentuan Pasal 1244 KUHPerdata dapat disimpulkan bahwa keadaaan memaksa adalah suatu peristiwa di mana debitur tidak dapat melaksanakan prestasi dengan baik yang diakibatkan oleh suatu hal yang tidak terduga dan juga tidak dapat dipertanggungjawabkan kepadanya, oleh karenya dibebaskan untuk mengganti biaya, rugi dan bunga. Dari Pasal 1244dan 1245 KUHPerdata dapat diketahui bahwa dengan adanya keadaan memaksa, maka akibatnya debtiur secara relatif terhindar dari kewajiban untuk memenuhi prestasi, selain dari pada itu debitur juga secara pasti terhindar dari tuntutan ganti rugi oleh kreditur.

Suatu hal yang erat kaitannya dengan unsur keadaan memaksa dalam pemenuhan prestasi adalah faktor risiko. Menurut Subekti, (2001:59) risiko adalah kewajiban untuk memikul kerugian jikalau ada suatu kejadian di luar kesalahan salah satu pihak. Berdasarkan hal tersebut berarti pihak yang berkewajiban tersebut adalah pihak yang menanggung risiko. Walaupun pihak tersebut tidak melakukan kesalahan, jadi risiko juga merupakan akibat adanya keadaan memaksa. Dalam Buku III KUHPerdata diatur perihal risiko pada pada perjanjian sepihak dan juga perjanjian jual-beli. Dalam perjanjian sepihak, risiko diatur dalam Pasal 1237 KUHPerdata yang menyatakan bahwa dalam hal adanya perikatan untuk memberikan suatu barang tertentu, maka barang itu semenjak perikatan dilahirkan, adalah tanggungan si berpiutang. Dengan demikian faktor risiko yang terdapat di dalam perjanjian sepihak misalnya di dalam perjanjian hibah, perjanjian pinjam-pakai dan sebagainya, KUHPerdata mengatur bahwa hal tersebut ditanggung kreditur selama debitur tidak lalai untuk menyerahkannya. Dalam hal ini walaupun debitur telah lalai melakukan penyerahan, risiko akan tetap ditanggung kreditur selama debitur dapat membuktikan benda tersebut tetap akan musnah walaupun telah diserahkan kepada kreditur. Pengaturan akan hal tersebut di dalam Pasal 1444 KUHPerdata. 
Berkaitan dengan faktor risiko bagi perjanjian timbal-balik, maka diatur secara tersendiri di dalam tiap-tiap bab yang mengatur perjanjian bernama yang bersangkutan. Mengenai perjanjian timbal-balik berupa jual-beli, dengan adanya Surat Edaran Mahkamah Agung Nomor 3 Tahun 1963 yang merupakan anjuran kepada hakim di pengadilan untuk menganggap Pasal 1460 KUHPerdata tentang risiko terhadap perjanjian jual-beli barang tertentu sebagian tidak berlaku lagi, karena dirasakan sebagai pasal yang tidak adil dan dengan alasan yang sama juga seharusnya diperlakukan terhadap Pasal 1461 dan 1462 KUHPerdata tentang risiko terhadap perjanjian jual-beli barang menurut berat, jumlah atau ukuran tertentu dan perjanjian jual-beli menurut tumpukan. Sehingga dengan demikian dalam perjanjian jual-beli selama belum terjadi penyerahan, maka risiko masih ditanggung penjual (Subekti,1995:27-28).

Mengenai pengaturan secara umum bagi perjanjian yang belum diatur secara khusus dalam Buku III KUHPerdata yang tidak memberikan aturan tersebut, maka harus didasarkan antara lain pada Pasal 1264 ayat (2) KUHPerdata, yaitu bahwa barang pokok perikatan musnah di luar kesalahan debitur, maka perikatan dianggap hapus. Di samping itu Pasal 1545 KUHPerdata yang menyatakan bahwa bila barang akan ditukar musnah di luar salah pemilik maka perjanjian menjadi gugur, dan siapa yang telah memenuhi perjanjian dapat menuntut kembali barang yang telah diserahkannya. Oleh karenanya dapat diketahui norma-norma umum dari peraturanperaturan yang mengatur risiko pada perjanjian timbale-balik adalah sepatutnya masing-masing pemilik itulah yang menanggung risiko terhadap barang miliknya. Dengan begitu ketentuanketentuan di atas dapat digunakan sebagai pengaturan secara umum terhadap risiko pada perjanjian timbal-balik atau dapat diterapkan bagi perjanjian timbal-balik yang risikonya belum diatur secara khusus.

8. Urgensi Perjanjian dalam Hubungan Hukum Perdata.

a) Pengertian hukum perdata

Hukum perdata adalah aturan-aturan atau norma-norma, yang memberikan pembatasan dan oleh karenanya memberikan perlindungan pada kepentingan-kepentingan perseorangan dalam perbandingan yang tepat antara kepentingan yang satu dengan yang lain dari orang-orang di dalam suatu masyarakat tertentu (Adiwimarta,1983:2). Hukum perdata bertujuan untuk mengatur sehingga didapati masyarakat yang damai dan adil. Subekti mengemukakan bahwa hukum perdata adalah segala hukum pokok yang mengatur kepentingan-kepentingan perseorangan (2002:1). Hukum perdata menentukan bahwa di dalam perhubungan antar mereka, 
orang harus menundukkan diri kepada apa saja dan norma-norma apa saja yang harus mereka indahkan.

Hukum perdata dalam arti luas adalah bahan hukum sebagaimana yang tercantum dalam Kitab Undang-undang Perdata (B.W) Kitab Undang-undang Hukum dagang (W.v.K.) beserta sejumlah yang disebut undang-undang tambahan. Hukum perdata dibagi menjadi dua yaitu hukum perdata materiil dan hukum perdata formil. Hukum perdata materiil adalah aturan-aturan hukum yang mengatur hak-hak dan kewajiban-kewajiban perdata itu sendiri, sedangkan hukum perdata formiil adalah menentukan cara, menurut mana pemenuhan hak-hak materiil tersebut dapat dijamin.

b) Pelaksanaan perjanjian

Salah satu aspek yang amat penting dalam perjanjian adalah perlaksanaan perjanjian. Bahkan dapat dikatakan bahwa pelaksanaan perjanjian inilah yang menjadi tujuan orang-orang yang mengadakan perjanjian. Karena justru dengan pelaksanaan perjanjian itu, pihak-pihak yang membuatnya akan dapat memenuhi kebutuhannya, kepentingannya serta mengembangkan bakatnya (Riduan Syahrani,2000:256). Perjanjian kalau dilihat dari wujudnya adalah merupakan rangkaian kata-kata yang mengandung janji-janji atau kesanggupan yang diucapkan atau dituangkan dalam bentuk tulisan oleh pihak-pihak yang membuat perjanjian. Dalam perjanjian itulah tercantum hak-hak dan kewajiban-kewajiban dari pihak yang membuatnya. Melaksanakan perjanjian berarti melaksanakan sebagaimana mestinya apa yang merupakan kewajiban terhadap siapa perjanjian yang dibuat. Oleh karena itu melaksanakan perjanjian pada hakikatnya adalah berbuat sesuatu atau tidak berbuat sesuatu untuk kepentingan orang lain yakni pihak yang berhak atas perlaksanaan perjanjian tersebut.

Sebagaimana telah dipaparkan pada awal tulisan ini bahwa perjanjian merupakan suatu perbuatan dengan mana satu orang atau lebih mengikatkan dirinya terhadap satu orang atau lebih.. dari peristiwa ini, timbullah suatu hubungan antara dua orang tersebut yang dinamakan perikatan. Kedua definisi di atas menimbulkan sifat mengikat antara satu orang atau lebih kepada orang lain untuk melakukan suatu hal. Hubungan hukum keperdataan selalu diawali dengan sebuah perjanjian. Sebagaimana diketahui bersama bahwa hukum perdata sebagai hukum yang yang mengatur kepentingan perseorangan (pribadi) yang berbeda dengan hukum public sebagai hukum yang mengatur kepentingan umum (masyarakat). Interaksi hidup manusia mengakibatkan seringnya diadakan perjanjian dalam lalu lintas hubungan hukum. Adanya kesepakatan antara 
kedua belah pihak menyebabkan diharuskannya diadakan perjanjian sebelum melakukan perbuatan hukum. Hal ini penting diadakan sebab sebagai sebuah agunan/jaminan dikemudian hari jika salah satu pihak wanprestasi.

\section{PENUTUP \\ C. Kesimpulan}

Perjanjian merupakan perbuatan hukum yang sangat penting dilakukan oleh para pihak dalam hubungan hukum perdata sebelum melaksanakan perbuatan hukum. Hal ini penting di lakukan demi tercapainya kedamaian dan keadilan para pihak. Perjanjian memuat hak-hak dan kewajiban-kewajiban apa saja yang harus dilakukan oleh para pihak, sehingga jika dikemudian

hari salah satunya wanprestasi maka dengan muda mengacu kepada isi perjanjian. Perjanjian dapat memberikan perlindungan hukum kepada para pihak. 


\section{DAFTAR PUSTAKA}

Afandi, Ali, 1986, Hukum Waris, Hukum Keluarga, Hukum Pembuktikan, Pt. Bina Aksara, Jakarta.

Badrulzaman, Mariam Darus, 1994, Aneka Hukum Bisnis, Alumni, Bandung

Masjchoen Sofwan, Sri Soedewi, 1980, Hukum Perdata-Hukum Perutangan Bag. B, Seksi Hukum Perdata Fak. Hukum Universitas Gadjah Mada, Yogyakarta

Mertokusumo, Sudikno, 1999, Mengenal Hukum Suatu Pengantar, Liberty, Yogyakarta.

2001, Penemuan Hukum Sebuah Pengantar, Liberty, Yogyakarta.

1993, Hukum Perikatan, (Perikatan Pada Umumnya), Alumni, Bandung.

Setiawan, R,. 1994, Pokok-Pokok Hukum Perikatan, Putra A Bardin, Bandung.

Sjahdeini, Sutan Remy, 1993, Kebebasan Berkontrak Dan Perlindungan Yang Seimbang Bagi Para Pihak Dalam Perjanjian Kredit Bank Di Indonesia, Institut Banker Indonesia.

Subekti. R., 1995 Aneka Perjanjian, P.T Citra Aditya Bhakti, Bandung.

Syahrani, Riduan, 2000, Seluk Beluk Dan Asas-Asas Hukum Perdata, Alumni, Bandung

Vollmar, H.F.A.,1984, Pengantar Studi Hukum Perdata Ii, Alih Bahasa: I.S. Adiwimarta, Rajawali, Jakarta. 